\title{
Lumen
}

Selected Proceedings from the Canadian Society for Eighteenth-Century Studies

\section{In the Groves of the Academy: The Aikin Family, Sociability, and the Liberal Dissenting Academy}

\section{Kathryn Ready}

Volume 34, 2015

URI : https://id.erudit.org/iderudit/1028509ar

DOI : https://doi.org/10.7202/1028509ar

Aller au sommaire du numéro

Éditeur(s)

Canadian Society for Eighteenth-Century Studies / Société canadienne d'étude du dix-huitième siècle

ISSN

1209-3696 (imprimé)

1927-8284 (numérique)

Découvrir la revue

Citer cet article

Ready, K. (2015). In the Groves of the Academy: The Aikin Family, Sociability, and the Liberal Dissenting Academy. Lumen, 34, 25-38.

https://doi.org/10.7202/1028509ar 


\title{
In the Groves of the Academy: The Aikin Family, Sociability, and the Liberal Dissenting Academy
}

\author{
KATHRYN READY \\ The University of Winnipeg
}

The Aikin family, including Anna Letitia Barbauld (née Aikin; 17431825) and her brother John (1747-1822), were closely connected with two famous liberal Dissenting academies: the Warrington Academy (1757-83) and the New College, Hackney (1786-96). ${ }^{1}$ The Warrington and Hackney academies belonged to two different identified phases in Dissenting sociability, the first characterized as "amiable," provincial, and politically non-interventionist and the second as "passionate," metropolitan, and politically radical. ${ }^{2}$ Yet close consideration of Barbauld's and her brother's respective poetic tributes to the Warrington and Hackney academies suggests significant continuities. In her 1773 poem

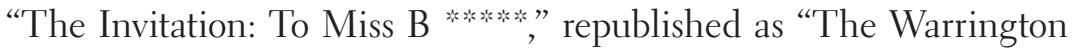
Academy" in 1774, Barbauld imagines the Warrington students learning to become critically engaged citizens through their encouraged

1. Alternative end dates sometimes given for Warrington are 1782 , when the last students were admitted, or 1786 , when remaining assets were officially redistributed. Standard works on the Dissenting academies include Herbert McLachlan, Education under the Test Acts: Being the History of the Non-Conformist Academies, 1662-1820 (Manchester: Manchester University Press, 1931).

2. Anne Janowitz, "Amiable and Radical Sociability: Anna Barbauld's 'Free Familiar Conversation," in Romantic Sociability: Social Networks and Literary Culture in Britain 1770-1840, eds. Gillian Russell and Clara Tuite (Cambridge: Cambridge University Press, 2002), 62-81. A comparable analysis of the history of Dissenting sociability appears in Jon Mee, “The Use of Conversation': William Godwin's Conversable World and Romantic Sociability," Studies in Romanticism 50.4 (2011): 567-9o. 
commitment to the liberal Dissenting principle of "free inquiry," and Aikin's 1791 poem "An Epistle to Mr. Aikin, Student in New College, Hackney" essentially reformulates the same argument. While Aikin invites co-religionists to become more politically outspoken than before, both he and his sister encourage a form of critically engaged patriotism fundamentally inspired by both the principle of "free inquiry" and a tradition of republicanism that was not that of Thomas Paine but rooted in ancient political thought.

From a variety of contemporary sources it appears that the individual who did the most to shape the character of Warrington sociability was John and Anna's father, the elder John Aikin (1713-80), Warrington tutor of belles-lettres from 1758 to 1761 and principal and tutor of theology, with continuing responsibility for teaching the classics, from 1761 until shortly before his death. According to Warrington alumnus William Turner, the elder John Aikin developed a "happy extemporaneous manner in which he ... excelled all other lecturers," encouraging students "to free familiar conversation, and even debate." 3 t the heart of his pedagogy was the liberal Dissenting commitment to "free inquiry," as he wished every student "to . . exercise . . . that liberty of declaring his own sentiments on any side of a question ... necessary to its fair investigation." As Turner further underscores, "the advantages ... derived ... were not confined to the lecture-room ... [as the elder John Aikin] had frequent small parties ... when he was accustomed quite to unbend, and enter with ... [students] into the most free familiar conversation," not only discussing course materials but also giving "his opinion of books, or of courses of reading on particular subjects" and recounting "anecdotes of his own youthful years."

Anne Janowitz has already sought to situate this model of "free familiar conversation" within the culture and politics of the period, citing it as representative of a particular phase in Dissenting sociability. While acknowledging "that current political issues were part and parcel of everyday enthusiasms" at Warrington, she characterizes its sociability "as informal, familiar and amiable," promoting "the virtues

3. William Turner, "Historical Account of the Warrington Academy," The Monthly Repository of Theology and General Literature 8.85-94 (1813): 88, 164, 166.

4. Turner, "Historical," 430.

5. Turner, "Historical," 169. 
of 'candid manners' and an 'active mind" but as not politically activist. ${ }^{6}$ Indeed, she considers Warrington sociability as predicated upon a deliberate dissociation of sociability from politics.

Yet such a characterization of Warrington sociability arguably overlooks the relationship that the Aikin family, and Barbauld, in particular, saw between "amiable" sociability and politics during the decades prior to the French Revolution. In her 1775 "Thoughts on the Devotional Taste, on Sects, and on Establishments," Barbauld recognizes the Dissenting commitment to "free inquiry" as enabling contemporary Dissenters to influence politics by facilitating "[c]onnections ... of intimacy, business," and "relationship" with the Establishment, in contrast to the generation before, when sectarians remained persecuted and isolated. Through cultivating connections with the Establishment while simultaneously retaining their "original purity," Dissenters were now ideally situated to "vindicate . . rights" such as that of "religious liberty" effectively. ${ }^{8}$

Besides that of "free inquiry," a concept arguably informing this history of sectarian sociability is that of "independence," familiar from a tradition of "eighteenth-century republicanism . . . that drew heavily on ancient and classical sources ... whose influence... [had been] revivified and concentrated by the writings of [Niccolò] Machiavelli and [James] Harrington." Following Polybius and Cicero, writers within this tradition endorsed a model of mixed government that combined elements of monarchy, aristocracy, and democracy, in contrast to the "[a]nti-monarchical republicanism" that existed "on the borders of political controversy throughout the eighteenth century."10 They believed that patriotism, which demanded the subordination of

6. Janowitz, “Amiable," 62, 65.

7. Anna Letitia Barbauld, Selected Poetry and Prose, eds. William McCarthy and Elizabeth Kraft (Peterborough: Broadview, 2002), 225.

8. Barbauld, Selected, 224.

9. Mark Philp, "Enlightenment, Republicanism, Radicalism," in The Enlightenment World, eds. Martin Fitzpatrick, Peter Jones, Christa Knellwolf, and Iain McCalman (New York: Routledge, 2004), 459-6o. For a more extensive treatment of Barbauld and Aikin in relation to eighteenth-century republicanism see my article "Dissenting Patriots: Anna Barbauld, John Aikin, and the Discourse of Classical Republicanism in Rational Dissent," History of European Ideas 38.4 (2012): 527-49. In this article, I also discuss "The Invitation" and "Epistle to Mr. Aikin" but do not develop the connection to the history of Dissenting sociability.

10. Philp, "Enlightenment," 458. 
private to public interest, required "independence" and "liberty," terms often employed interchangeably, with liberty understood in the Ciceronian sense of serving no master. ${ }^{11}$ Among ancient political thinkers, Aristotle underscores the importance of independence, for example, in insisting that "a state is fully realized only when ... the community of numbers is self-sufficing."

In reaction to a longstanding assumption that eighteenth-century political thought fell generally within the parametres of liberalism, scholars such as J. G. A. Pocock have sought to foreground the importance of a classically derived republicanism at the expense of liberalism, although a growing number accept that the two were never mutually exclusive (something confirmed by the "Thoughts," which brings together the concept of "independence" with the language of natural rights). ${ }^{13}$ As Mark Philp emphasizes, many scholars have historically assumed "[a] fundamental incompatibility . . . between socialcontract arguments and the commitments of the republican tradition, yet the traditions often interleave without embarrassment."14 Michael P. Zuckert explains that much of this perceived incompatibility stems from a confusion over the difference between "political science" and "political philosophy," and that "[m]ost of what is currently discussed as classical republicanism is political thought at the level of political science; most of what is discussed as liberalism is reflection at the level of political philosophy." 15

"Independence," evidently, was not necessarily synonymous with a critically engaged patriotism. The younger John Aikin later dismissed the uncritical patriotism of such Roman heroes as the Curtii and Decii, complaining that it disregarded "considerations of general justice and benevolence."16 An exemplar of critically engaged patriotism the Aikins did recognize among the ancients was Cicero. In her poem

11. Cicero, De re publica. De legibus, trans. Clinton Walker Keyes, 1928 (Cambridge: Harvard University Press, 2006), 153.

12. Aristotle, Politics, trans. H. Rackham, 1932 (Cambridge: Harvard University Press, 2005), 75 .

13. See, for example, J. G. A. Pocock, Virtue, Commerce, and History (Cambridge: Cambridge University Press, 1985).

14. Philp, "Enlightenment," 466.

15. Michael P. Zuckert, Natural Rights and the New Republicanism (Princeton: Princeton University Press, 1998), 165.

16. John Aikin, Letters from a Father to his Son (London, 1793-1800), I: 303, 304. 
"The Times," composed and circulated privately during the 1760 , Barbauld parallels the situation of Great Britain under George III and that of Rome under Julius Caesar, recognizing Cicero's denunciation of efforts to break the "spirit" of the Roman republic and celebrating Brutus' successful defeat of tyranny with "one well aimed blow" (7), a victory she saw as only possible because, unlike in her own day, "lust of gold" (13) had not yet become completely pervasive. ${ }^{17}$

In "The Invitation," the poet posits the principle of "free inquiry" as a foundation for independence and critically engaged patriotism in the implied contrast between "th' inquiring youth" (95) of Warrington who "court the fair majestic form of truth" (96) and the students at Establishment schools who are taught to court the favour of the great and personal advancement. ${ }^{18}$ Again, "independence" is not a word explicitly used but indirectly conveyed. Throughout "The Invitation," the poet represents the Warrington students not only as readers of "the classic page" (113) but also as the modern descendants of ancient patriots, their souls feeding "[o]n pictur'd tales of vast heroic deeds; / And quick affections, kindling into flame / At virtue's, or their country's honour'd name" (122-24). Amidst "green retreats" (79), the Warrington students learn "generous scorn of vice's venal tribe" (127) and "proud disdain of interest's sordid bribe" (128), something that will enable future politicians among them to "plead" their "country's cause / And vindicate the majesty of laws" (169-70) with "patriot passion . . . I Ardent" (167-68).

Barbauld arguably innovates within the republican tradition cited above in insisting that it was commitment to "free inquiry" that had enabled Warrington students to maintain their independence despite their own close association with commerce. The poet of "The Invitation" implies that all Warrington students, including those who will later follow a "vent'rous course" over "seas and rocks" (146) in order to bring home "[f]rom every land the various harvest spoil" (149), will be able to claim the title of patriot in the classical republican sense, because of their commitment to "free inquiry."

17. Significantly, Aikin traces the origins of the principle of "free inquiry" to the ancients in a short prose piece "Inquiry into the Essential Character of Man," reprinted in Lucy Aikin, Memoir of John Aikin, M.D. (Philadelphia, 1824), 348-54.

18. My source for Barbauld's poetry is William McCarthy and Elizabeth Kraft, eds., The Poems of Anna Letitia Barbauld (Athens: University of Georgia Press, 1994). 
Thus, the poet circumvents a problem that she and her brother faced in appropriating classical republican rhetoric: the awareness that Dissenters belonged to the commercial middle classes rather than to the landed gentry. The ancient sources from which mainstream eighteenth-century republicanism took inspiration convey general misgivings about commerce. If Aristotle accepted that "the ideal of the state is to consist as much as possible of persons that are equal and alike... [and that] this similarity is most found in the middle classes" and allowed the middle classes greater independence than "the poor," since the former did "not . . . covet other men's goods," he expressed profound suspicion of money-based commerce, which he believed tended inevitably to corruption, privileging those who owned property over those engaged in commerce. ${ }^{19}$ As has been established by Pocock among others, the widespread acceptance that commerce was necessary to the prosperity of eighteenth-century Britain did not negate widespread anxiety concerning the tension between commerce and virtue taken for granted by classical republicans.

In other poems written during her Warrington days, such as "The Times" and her famous "Corsica" (1768-69; 1773), in which the poet speaks for "the mountain goddess" (75) Liberty, who claims the Corsicans as "[h]er genuine sons, / A broken remnant, from the generous stock / Of ancient Greece, from Sparta's sad remains” (85-87), Barbauld explores the claims that Dissenters (female Dissenters included) might make, not only as classical republican but also specifically as Ciceronian patriots (in the first poem criticizing the perceived efforts of George III to upset the balance of the mixed constitution and in the second poem the British government's failure to support the Corsican cause of independence).

While Janowitz downplays the importance of political engagements at Warrington, she argues that Barbauld was significantly politicized by her move to London in 1786. In her view, the relocation to London and participation in an "intellectual circle of Dissenters and radical reformers who made up ... [London-based bookseller and publisher Joseph Johnson's] list," including William Godwin, Mary Wollstonecraft, and

19. Aristotle, Politics, 331. For ancient expressions of suspicion towards commerce see, for example, Aristotle, Politics, 39 and Cicero, De officiis, trans. Walter Miller, 1913 (Cambridge: Harvard University Press, 2001), 155. 
Paine, led Barbauld to embrace a different model of sociability "shaped from a more urban and militant notion of sociability linked to political activism ... and which structured an interventionist poetic" that "aimed to eschew manners for the power of analysis." ${ }^{20}$

It is true that during the years immediately following the French Revolution Barbauld and her brother produced a large body of prose and poetry addressing political subjects, much of which might be fairly described as "passionate" and "interventionist," and that in this writing London acquires increased prominence as a reference point. As Janowitz has already pointed out, the world of urban tavern culture is the backdrop for such poems as Barbauld's "Lines to Samuel Rogers in Wales on the Eve of Bastille Day, 1791" (1791), in which the poet encourages Hackney student Samuel Rogers to abandon the "fairy streams" (5) of Wales in order to attend the second anniversary Bastille Day celebration being held at the London Crown and Anchor tavern.

One notable urban reference point in the writings of the Aikin family from this period is Hackney, the site of the New College. Aikin sent his son Arthur to the New College in 1789, and when the rest of the family moved to London in 1791 John became a governor there. By this point, Barbauld's husband Rochmont was already serving on the examinations board. Based particularly on its association with tutors Richard Price and Joseph Priestley, the college itself was identified in the 1790 s as a site of Dissenting radicalization, and it is likely the Hackney academy Edmund Burke has in mind when he melodramatically warns in Reflections on the Revolution in France (1791) that "[i]n the groves of ... [the Dissenting] academy, at the end of every vista, you see nothing but gallows." ${ }^{21}$

Yet the Aikins would not necessarily have seen the New College as representing anything particularly new in the history of the Dissenting academy. The Hackney academy had inherited part of Warrington's remaining assets and among Dissenters at least had come "to be regarded as ... [its] main successor."22 Priestley had, of course, first been

20. Janowitz, "Amiable," 62.

21. Edmund Burke, Reflections on the Revolution in France, ed. J. C. D. Clark (Redwood City: Stanford University Press and Cambridge: Cambridge University Press, 2002), 240.

22. David L. Wykes, "The Dissenting Academy and Rational Dissent," in Enlightenment and Religion: Rational Dissent in Eighteenth-century Britain, ed. Knud Haakonssen (Cambridge: Cambridge University Press, 1996), 131. 
a tutor at Warrington, and the academies had at least one other tutor in common: Gilbert Wakefield. Hackney's own library would later merge with Warrington's at another Dissenting academy, Manchester College.

In the political writings they produced during the early 1790s, Barbauld and her brother both played up their connection with Price and Priestley. While Barbauld had already publicized her friendship with Priestley in another 1773 poem, "The Mouse's Petition," it had been widely taken to be critical of his scientific practice. Her poem "To Dr. Priestley. Dec. 29, 1792," written after Priestley had been targeted by mobs in the Birmingham Riots, left no room to doubt her loyalty to him. By this point, her brother had already published "Sonnet to the Rev. Joseph Priestley," in which he laments Priestley as the victim of "bigot's rage" (10), and "Sonnet to Richard Price," which imagines Price "arm'd with Reason's panoply divine, / And train'd by Virtue" (2-3), leading a "stedfast phalanx" (4) of "Liberty" (4). ${ }^{23}$ Aikin concludes An Address to the Dissidents of England on their Late Defeat (1790) with a loose quotation from Price's Discourse on the Love of our Country (1789), which notably has been seen as promoting a model of patriotism that encourages citizens to "'correct and purify' their country, and. . . to 'enlighten' and 'liberalize it."'24 According to Rémy Duthille, Price had come to adopt a critically engaged patriotism in part through his involvement in ongoing debates "on universal benevolence and partial affections . . looking back to the Stoic concept of oikeiosis," a concept which imagines the ties of human affection rippling outwards from immediate family to local community, to country, and ultimately to humanity at large, and virtue as consisting in the ability to prioritize the broader over the narrower interest. ${ }^{25}$ As Duthille notes, in the eighteenth century Cicero was often selectively invoked by those attempting to assert the primacy of national over any other interest, but Price invokes him rather differently, in order to question immoral action in the name of patriotism. ${ }^{26}$ Barbauld's Address to the Opposers

23. My source for Aikin's poetry is John Aikin, Poems (London, 1791).

24. See John Aikin, An Address to the Dissidents of England on their Late Defeat (London, 1790), 32; Richard Price, A Discourse on the Love of our Country (London, 1789), 49-50; and Rémy Duthille, "Richard Price on Patriotism and Universal Benevolence," Enlightenment and Dissent 28 (2012): 28.

25. Duthille, "Richard," 30.

26. Duthille, "Richard," 34, 30. 
of the Repeal of the Corporation and Test Acts (1790) subtly evokes Price in the memorable image of "the spirit of Inquiry, [which] like a severe and searching wind, penetrates every part of the great body politic." 27 The phrase "spirit of Enquiry" appears in a sermon Price originally delivered to a Dissenting audience at Hackney (although Barbauld's association of "free inquiry" elsewhere with "independence" has no exact correspondence in either Price or Priestley). ${ }^{28}$

At the same time as they declared allegiance to Price and Priestley, however, the Aikins continued to maintain their distance from Godwin, Wollstonecraft, and Paine. That the Aikins knew all three socially appears from various sources, and they evidently shared common connections in addition to Johnson (Wollstonecraft having met Price at Newington Green when she operated a girls' school there from 1784 to 1786) as well as through the Hackney academy (in a notorious incident a group of Hackney students inviting Paine to an honourary supper in June of 1792). ${ }^{29}$ Aikin admired Paine as "the most distinguished" of Burke's "literary antagonists" and later praised the Rights of Man (1791) as "so well adapted to common feeling and comprehension, that it greatly contributed to the diffusion of democratical principles and a spirit of reform through the kingdom." ${ }^{30}$ Like Paine, he and his sister explicitly considered "free inquiry" a natural right, and the language of natural rights is generally prominent in their political writings of this period. ${ }^{31}$ However, neither espoused Paineite republicanism, which rejected monarchy and aristocracy and advocated "a government by representation-founded upon the principles of the Declaration of Rights."32 Instead, Aikin declared support for the "mixed constitution"

27. Barbauld, Selected, 277 .

28. Richard Price, The Evidence for a Future Period of Improvement in the State of Mankind (London, 1787), 52.

29. While sources are scantier for Wollstonecraft than for Paine or Godwin, a letter dated to 1797 from nephew and adopted son Charles Aikin to Barbauld describes one of Wollstonecraft's sisters as "more reserved" but possessed of the same "good sense" as Wollstonecraft, suggesting past social encounters by which to make the comparison. As quoted in Betsy Rodgers, Georgian Chronicle: Mrs. Barbauld o her Family (London: Methuen \& Co., 1958), 219.

30. John Aikin, Annals of King George (London, 1830), I: 423.

31. Paine identifies "intellectual rights, or rights of the mind" among the "natural rights" in Rights of Man (London-Derry, 1791), 25. Aikin, for example, defends "free inquiry" as a natural right in Letters, II: 75.

32. As quoted in Moncure Daniel Conway, ed., The Writings of Thomas Paine (New York and London: G. P. Putnam's Sons, 1895), III: 9. 
against "pure monarchy" and professed the "habits" of "Dissenters" and "all their earliest associations" as predisposing them to "limited monarchy." ${ }^{33}$ Despite their radical reputations, Price and Priestley never came out clearly in favour of what has been termed "democratic republicanism” either, at least not with respect to Great Britain, and have been characterized as "blend[ing traditional] republican elements with a wide range of other influences." 34 Like the Aikins, they believed in natural rights, including the natural right of "free inquiry," but as far as concerned government Price professed merely the desire to "restore ... [the mixed constitution] to purity and vigour, by removing the defects in our representation, and establishing that independence of the three states on one another," declaring, "I know not one individual among ... [Protestant Dissenters] who would not tremble at the thought of changing into a Democracy our mixed form of government." 35 As well as preferring "limited monarchy" to "democratic republicanism," Aikin appears to have been put off by his social encounters with Paine, judging him "not like a gentleman, nor very agreeable in conversation." ${ }^{36}$ The family seems to have found Godwin and Wollstonecraft more personally congenial than Paine, and Aikin commended A Vindication of the Rights of Woman (1792) as "full of good observations," but at the same time he worried about it "inculcating quite a masculine character in the sex." ${ }^{37}$ Barbauld's oftcited poem "The Rights of Woman" (1792), which concludes with the assertion "[t]hat separate rights are lost in mutual love" (32), registers a shared ambivalence, and William McCarthy speculates further that a particular passage in Barbauld's Sins of the Government, Sins of the Nation (1793) reflects at least one point of disagreement with Godwin's Enquiry concerning Political Justice (1793). ${ }^{38}$

Nor would the Aikins have necessarily agreed that it was Godwin, Wollstonecraft, and Paine who set the tone at Johnson's or that Johnson

33. John Aikin, The Spirit of the Constitution and that of the Church of England compared (London, 1790), 8, 11.

34. Philp, "Enlightenment," 462.

35. Price, Discourse, 31.

36. As quoted in Rodgers, Georgian, 132.

37. As quoted in Anna Letitia Le Breton, Memoirs of Seventy Years, by One of a Literary Family, ed. Mary Emma Martin (London: Griffith \& Farran, 1883), 21.

38. William McCarthy, Anna Letitia Barbauld: Voice of the Enlightenment (Baltimore: The Johns Hopkins University Press, 2008), 335. 
himself could be counted as radical. Following the French Revolution members of the Establishment such as Sarah Trimmer did break with Johnson over his perceived radicalism. Towards the end of the decade, Johnson would spend six months in King's Bench prison for publishing an allegedly seditious treatise by Wakefield. Yet he had notably declined to publish the Rights of Man seven years earlier. Aikin later recalled an "amiable" rather than a "passionate" sociability at Johnson's. By his account, Johnson was a man who sought "literary connexions ... among Free Enquirers both on religious and political topicks" and who encouraged "large and liberal discussion" within "limits," hating "turbulence and sedition." ${ }^{39}$ Aikin further relates that even "during the height of party animosity, so little was ... [Johnson] regarded . . . as a party-man, that he continued to number among his intimate friends, several worthy persons of opposite sentiments and connexions, who, with himself, were capable of considering a man's performance of the duties of life apart from his speculative opinions." ${ }^{\prime 4}$

As his dedicatory sonnet to Price attests, the French Revolution had no effect upon the continuing inspiration Aikin took from classical republicanism, and his "Epistle to Mr. Aikin" affirms that the political role he envisions for Dissenters during this period marks an inheritance rather than a departure from Warrington. As Stephen Burley notes, "[i]n many respects ... [the latter poem] can be read as a companion piece to . . 'The Invitation." "4l Indeed, the poet of "Epistle to Mr. Aikin" begins by recalling the "close talk" (6) he enjoyed with his young son Arthur on "Mersey's bank" (6). Following his sister, Aikin highlights the governing principle of "free inquiry" at the liberal Dissenting academy, asserting that here

[n] o slavish forms betray ingenuous youth, And early quench the native zeal for truth; Train pliant souls to take a master's bent, School'd in the discipline of blind assent;

39. John Aikin, "Biographical Account of the Late Mr. Joseph Johnson," The Gentleman's Magazine 79, part 2 (1809), 1167.

40. Aikin, "Biographical," 1167-68.

41. Stephen Burley, New College, Hackney (1786-96): A Selection of Printed and Archival Sources, 2nd ed. (London: Dr Williams's Centre for Dissenting Studies, 2011), 192, available at http://www.english.qmul.ac.uk/drwilliams/pubs/nc\%2ohackney. html. 
No mystic creeds chalk out their narrow line,

Nor human systems claim a right divine;

No sordid interest prompts th' unrighteous fear,

Lest learning search with spirit too sincere ... (25-32)

Simultaneously, he makes a familiar case that the commitment to "free inquiry" provided Hackney students with a foundation for independence and critically engaged patriotism. The poet develops the connection between "free inquiry," independence, and patriotism at the end of the poem, where he credits Hackney tutors such as Price and Priestley with producing both " $\mathrm{t}$ ]he bold Assertor of the freeborn mind" (53) and "[t]he patriot firm, whose unsubmitting soul / Nor flatt'ry melts, nor menaces controul" (58-59).

Perhaps what mainly differentiates the two poems is the pointedness and outspokenness with which Aikin criticizes members of the Establishment, who are accused of preferring their children " $s]$ chool'd in the discipline of blind assent" and of endorsing "human systems" that claim a "right divine." With the reference to "human systems" that claim a "right divine" the poet seems to condemn not only the historical institution of absolute monarchy but also George III's own efforts to revive royal prerogative (a theme of "The Times") and the pretensions of state-allied religion.

It is true that Hackney was a more politically charged atmosphere than Warrington's. In addition to Price and Priestley, a dominant personality at Hackney was Thomas Belsham, who openly advocated "passionate" political interventionism by Dissenters, declaring, "We have tried long enough what trimming, and moderation, as it is called, will do ... It is now high time to try the effect of simplicity and integrity. Let us avow the truth-let us be willing to suffer for it." ${ }^{\prime 2}$

However, admiration of Hackney did not change the fact that Aikin attributed his own development of a critically engaged patriotism to his time at Warrington. As he later emphasized, it was not "from parental instruction and example" that he initially failed as a "discriminating lover of his country." 43 Lucy Aikin dates her father's politicization and transition from an "ardent" patriot to one capable of

42. As quoted in John Williams, Memoirs of the Late Reverend Thomas Belsham (London, 1833), 427 .

43. John Aikin, Letters, I: 304. 
"critical judgment upon the wisdom or rectitude of those counsels by which ... [national] affairs are conducted" to the period after he returned to Warrington, where he had been a student, in order to teach part-time, and more specifically, to "the free discussions of fundamental principles . . called forth" by the American Revolution (1775-83). ${ }^{44}$ Indeed, his daughter leaves it to be inferred that some of the formative "free discussions" her father had on the subject of America were as a colleague to his own father, whom another Warrington tutor William Enfield characterized explicitly as a patriot who at once "prayed for the prosperity of his country" and "lamented the disorders and corruptions of the state." 45 Thereafter, Lucy Aikin relates, the younger John Aikin "became a strenuous supporter of the cause of liberty, in whatever quarter of the world her banner was displayed." 46 He would publicly condemn British policy towards America in his 1790 Address, but the groundwork had clearly been laid long before. ${ }^{47}$ That same year, he would address a sonnet to his sister, urging, "Seize, seize the lyre, resume the lofty strain! / 'Tis time, 'tis time! Hark how the nations round / With jocund notes of liberty resound,-/ And thy own Corsica has burst her chain!" (9-12). Significantly, the call is not for new but for renewed political engagement, the poet acknowledging Barbauld's own politicization during the 1760 s, at a time when he himself remained an "ardent" rather than "discriminating" patriot.

The recognition of continuities between the Warrington and Hackney academies in their common association with a critically engaged patriotism lends significant support to the work of other scholars who have looked at sociability and the eighteenth-century Dissenting academy. Ana Acosta notes that "[d]uring the last decades of the century, education and radicalism were particularly associated in the [Dissenting] networks of sociability of northeast London," but she simultaneously stresses that "[m]any of the ideas that would become staples in the radical political circles of the reign of George III had long

44. Lucy Aikin, Memoirs, 32, 33.

45. William Enfield, Funeral Sermon, occasioned by the Death of the late Rev. John Aikin, D.D. (Warrington, 1781), 15.

46. Lucy Aikin, Memoirs, 35 .

47. Duthille dates the beginning of Price's critically engaged patriotism likewise to the years of the American War, noting that the latter felt no conflict between national and universal interest during the Seven Years' War, which he considered just from the British perspective. See Duthille, "Richard," 34. 
been disseminated in the curriculum of the dissenting academies." 48 Among the ideas Acosta mentions specifically in this category is that of "free inquiry." As attested by the Aikins, the ideas of "free inquiry" and "independence" provided Dissenters with ongoing inspiration in engaging with eighteenth-century politics, carrying over from the 1770 and 1780 into the heady years of the early 1790 .

48. Ana Acosta, "Spaces of Dissent and the Public Sphere in Hackney, Stoke Newington, and Newington Green,” Eighteenth-Century Life 27.1 (2003): 9. 